\author{
Dietrich Benner, Dariusz Stępkowski \\ Uniwersytet Kardynała Stefana Wyszyńskiego \\ w Warszawie
}

\title{
Jaskinia jako metafora opisująca procesy kształcenia Studium transformacji Platońskiej opowieści o jaskini w dyskursach edukacyjnych
}

Od powstania paraboli Platona wielu badaczy, opisując i interpretując procesy wychowania i kształcenia, odwoływało się i nadal odwołuje do motywu jaskini. Poniższe rozważania rozpoczynamy od prezentacji dwóch skrajnie odmiennych sposobów odczytania Platońskiej opowieści. Pierwszy z nich pochodzi od Hansa Blumenberga, autorem drugiego jest zaś Eugen Fink. W drugim punkcie przedstawiamy własną próbę uchwycenia sensu mitu Platona, w której szczególny nacisk położony jest na przesłanie edukacyjne tego obrazu. Trzeci punkt zawiera wybrane przykłady korzystania z toposu jaskini zarówno w nowożytnych, jak i współczesnych dyskursach na temat kształcenia. Następnie, wychodząc od koncepcji wychowania Friedricha D. E. Schleiermachera oraz Johanna F. Herbarta, rozważamy kwestię ciągłości i nieciągłości starożytnego oraz nowożytnego myślenia na temat wychowania i kształcenia. W końcu zaś, w piątym punkcie, nasza uwaga koncentruje się na pytaniu: czy współcześnie warto jeszcze odwoływać się do metafory jaskini przy opisywaniu i wyjaśnianiu procesu kształcenia? Naszym zdaniem, aby w pełni móc odpowiedzieć na to pytanie, trzeba dogłębnie zbadać rolę negatywnych doświadczeń w nauczaniu i uczeniu się. Wiadomo, że już Platon uważał je za warunek niezbędny do zrozumienia zależności między kształceniem a niekształceniem.

\section{Dwie wykładnie Platońskiego mitu o jaskini}

Chyba trudno byłoby sobie wyobrazić dwie bardziej sprzeczne interpretacje mitu Platona od tych, które przedstawili Blumenberg i Fink w swoich dziełach - odpowiednio Höhlenausgänge (Wyjścia z jaskini) i Metaphysik der Erziehung (Metafizyka wychowania). Pierwszy z nich tworzy z metafory jaskini obszerną fenomenologię. Blumenberg wychodzi od ,jaskini życia”, którą jest łono matki. Następnie przechodzi od jaskini jako formy (pra-)ludzkiego życia w epoce 
kamiennej przez ,jaskinię w ramach państwa” aż do ,jaskiń rozumu”. Autor ten widzi w paraboli Platona przede wszystkim tekst, który podkreśla ogromne znaczenie wychowania, choć równocześnie - niechcący - zaświadcza o jego niemocy.

Sposób postępowania Finka jest całkowicie odmienny. O paraboli jaskini pisze następująco: „Platon [...] opisał w niej pierwotną sytuację człowieka, jego skazanie na egzystencję z dala od bycia i niedające się oddzielić od ludzkiej natury poszukiwanie tego bycia”. Jego zdaniem mit jaskini traktuje o „kształceniu” (paideia) i „niekształceniu” (apaideusia). Dla Finka „rozstrzygające” jest to, że według Platona

nie wolno patrzeć na kształcenie tylko jak na sublimację prymitywnego stanu natury; do uchwycenia pełnego sensu kształcenia można dotrzeć [...] jedynie przy uwzględnieniu otwartości człowieka na bycie ${ }^{2}$.

Pytając o przesłanki, które skłoniły Blumenberga do pominięcia kwestii ważnych z punktu widzenia teorii kształcenia, od razu można wymienić dwie z nich. Pierwsza wynika z przyjęcia ewolucyjno-biologicznego punktu widzenia. Blumenberg rozpoczyna swoje analizy od domysłów, z których buduje wątpliwą analogię między życiodajną jaskinią matczynego łona a odnalezionymi w ostatnich czasach jaskiniami ludzi pierwotnych z mezolitu. Macierzyństwu, odczytanemu w sposób naturalistyczny, przypisuje on ważną funkcję w procesie przetrwania ludzkości. Druga przesłanka wiąże się z tym, że Blumenberg nie darzył szczególną sympatią pedagogiki emancypacyjnej. Jak się wydaje, właśnie to nie pozwoliło mu głębiej wniknąć w sens Platońskiego mitu. W pierwszej części swojego dzieła, zatytułowanej Erinnerung an den Anfang (Wspomnienie o poczatku) autor odczytuje parabolę jaskini jako obraz przedstawiający wyjście i opuszczenie jaskini. Tym, co Blumenberg całkowicie pomija, są ,początki uczenia się" związane z przystosowaniem (wżyciem) do sytuacji jaskini i podejmowane już w niej pierwsze próby przezwyciężenia własnych ograniczeń3 ${ }^{3}$ Swoją nadmierną ostrożność przy analizie problemów edukacyjnych autor uzasadnia tym, że nie jesteśmy w stanie „pomyśleć początku czasu”", pytać zaś o to nie możemy inaczej jak tylko „w czasie" o nie jest niemożliwe bez uwzględnienia czasowości; tylko i wyłącznie w ramach niej człowiek może się zastanawiać nad swoją historią uczenia się. Ta konstatacja przekonuje nas do tego, by „wyjść z jaskini” nie analizować tylko pod kątem powodów znalezienia się w niej człowieka oraz możliwości jej opuszczenia, co

\footnotetext{
${ }^{1}$ E. Fink, Metaphysik der Erziehung, Frankfurt am Main 1970, s. 40.

${ }^{2}$ Tamże.

${ }^{3}$ Por. K. Mayer-Drawe, Anfänge des Lernens, [w:] D. Benner (red.), Erziehung - Bildung Negativität, 4 - zeszyt tematyczny „Zeitschrift für Pädagogik” [Weinheim] 2005, s. 24-37.

${ }^{4}$ H. Blumenberg, Hohlenausgänge, Frankfurt am Main 1989, s. 11.

${ }^{5}$ Tamże.
} 
zawęża problematykę uczenia się. Warto też skierować refleksję na pytania: jak człowiek przez uczenie się może przystosować się do jaskini oraz jakiego wysiłku wymaga od niego uświadomienie sobie własnej sytuacji i wyjście z niej przez kształcenie?

Przypowieść Platona, zgodnie z Blumenbergowską wykładnią, jest równocześnie mimowolnym poświadczeniem „bezradności postępowania dialogiczne-

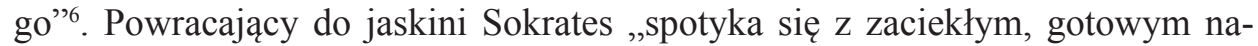
wet na morderstwo sprzeciwem tych, dla których dobra [podjął] cały wysiłek"7 paidei. To dowodzi, zdaniem Blumenberga, że: „Nic nie jest trudniejsze od skłonienia innych, aby przyjęli oferowaną wolność"s. W kontekście tego autor Höhlenausgänge konstatuje:

W przypowieści tej nie dochodzi do ostateczności tylko dlatego, że wracającemu [do jaskini] filozofowi nie zależy, żeby sprawy zaszły aż tak daleko. Jako „konsekwentny” paideutes musiałby paść wtedy ofiarą paidei. Trudność rozważenia wyjść z jaskini wynika stąd, że nie da się za pomocą jaskini zademonstrować, czym ona jest. Nieprzypadkowo więc Sokrates musi przemocą wywlec z podziemnej komory jednego [z owych kajdaniarzy], który zgodnie z programem miał tego na sobie doświadczyć. Nic by nie dało, gdyby zachęcał go, żeby sam stamtąd wyszedł ${ }^{9}$.

Zgodnie z interpretacją Blumenberga dialog z i między mieszkańcami jaskini rozpoczyna się dopiero po tym, gdy jednego z nich wyzwolono z kajdan, wypędzono na zewnątrz, po czym zmuszono do powrotu do jaskini, wbrew jego woli. Autor wyraźnie rozmija się z tekstem Platona, który rozmowy na różne tematy osadza w codziennych dyskusjach prowadzonych przez mieszkańców pieczary. Również konsekwencje, jakie założyciel ateńskiej Akademii wyciąga ze swojej opowieści, są diametralnie różne od tych, które sugeruje czytelnikom Blumenberg. Co więcej, u tego ostatniego sposób odczytywania przypowieści o jaskini jako lekcji o nieuchronnej „porażce dialogu”10 całkowicie odbiega od zamysłu Platona. Być może najbardziej zniekształcający fragment interpretacji Blumenberga brzmi następująco:

Środki, którymi dysponuje powracający [do jaskini], nie są wystarczające, żeby wzbudzić u innych chęć przejścia tej samej drogi wyzwolenia, którą on przeszedł; jest tak dlatego, że dialog już ze swej natury nie może tego osiągnąć. Ten, który wrócił [do pieczary], ponosi klęskę, ponieważ chce podobnie jak Sokrates pozostać wierny swojemu powołaniu ${ }^{11}$.

\footnotetext{
${ }^{6}$ Tamże, s. 87.

${ }^{7}$ Tamże.

${ }^{8}$ Tamże.

${ }^{9}$ Tamże, s. 89.

${ }^{10}$ Tamże, s. 88.

${ }^{11}$ Tamże. W sprawie krytyki tej interpretacji por.: H. Niehues-Pröbsting, Platonvorlesungen. Eigenschatten - Lächerlichkeiten, [w:] F. J. Wetz, H. Timm (red.), Die Kunst des Überlebens. Nachdenken über Hans Blumenberg, Frankfurt am Main 1999, s. 341-368.
} 
Nawiązując do Kanta, Blumenberg rozszyfrowuje przypowieść o jaskini jako wczesny przykład ,dylematu idei >niepełnoletności zawinionej przez siebie samego $" 12$. Chodzi tu o konieczność akceptacji przez uzurpujący sobie pełnię wiedzy „rozum [...] możliwości popadnięcia w samozaślepienie”13, którego nie może on z góry przewidzieć ani wykluczyć. W interpretacji Blumenberga nie ma śladu dialogu Platona z czytelnikiem ani tego, który prowadzą między sobą osoby przebywające w jaskini. Gdy się jednak uwzględni istnienie takiej komunikacji, wówczas w tekście Platona można natrafić na zupełnie inne odpowiedzi na pytanie postawione przez Blumenberga odnośnie do „funkcji mitu o jaskini w dyskursie na temat państwa" ${ }^{14}$. Opisana przez Platona parabola przestaje również być dowodem ,arogancji” wychowania, którego celem jest samowyzwolenie człowieka. Dobrze widoczny jest też problem kształcenia, o którym Fink - w swojej kosmologicznej interpretacji tekstu Platona - pisze, że człowiek z racji swej natury jest nieustannie weń uwikłany ${ }^{15}$.

\section{Metafora jaskini jako symbol początków uczenia się i ich znaczenie w wychowaniu, ksztalceniu i polityce}

W tym miejscu nie odczytujemy opowieści Platona jako mitu, który traktuje o w gruncie rzeczy jałowym dążeniu człowieka do samoupewnienia, lecz w kontekście ukształcalności i kształcenia próbujemy uchwycić trzy podstawowe wątki tej historii: po pierwsze, wyjście z jaskini, po drugie, przystosowanie się do jaskini, i, po trzecie, próbę jej opuszczenia.

Na początku siódmej księgi Państwa (514a) Platon wyznacza człowiekowi pozycję między niekształceniem (apaideusia) a kształceniem (paideia). Jest on istotą uczącą się, która już w swojej naturze ma zapisaną potrzebę wychowania. Kierunek kształcenia człowieka i cała jego egzystencja są określone w ten sposób, że co prawda niekształcenie jest punktem wyjścia kształcenia, jednak to ostatnie jest zawsze dane (bez początku). W związku z tym niekształcenie nie oznacza wcale jakiegoś braku ludzkiej natury, lecz jest jej momentem konstytutywnym; innymi słowy: ludzka natura od początku jest nastawiona na kształcenie. Dzięki temu człowiek przez uczenie się może z jednej strony radzić sobie z własną niegotowością (niedoskonałością), z drugiej natomiast musi w swoim myśleniu i działaniu zająć wobec niej stanowisko.

Opowiadanie Platona rozgrywa się „,w podziemnym pomieszczeniu na kształt jaskini” (514a) ${ }^{16}$. Żyją tam ludzie, którzy „siedzą od dziecięcych lat w kajdanach”

\footnotetext{
12 Tamże, s. 90.

13 Tamże.

14 Tamże, s. 95.

${ }^{15}$ Por. E. Fink, Metaphysik..., s. 43 i n.

${ }^{16}$ Przytoczenia pochodzą z: Platon, Państwo, przekł. W. Witwicki, Warszawa 1990.
} 
(514a). W miejscu ich pobytu światło pada z dwóch niezależnych źródeł. Przez długi na całą szerokość jaskini otwór wejściowy dociera światło pochodzące od nieznanej jasności. Czytelnicy dowiadują się, że jest nią słońce, które ogrzewa wszystkie byty i utrzymuje je w istnieniu. Drugie światło pochodzi z samej jaskini - jego źródłem jest ognisko płonące za plecami mieszkańców pieczary, którego jednak nie mogą widzieć, ponieważ ,przykute mają nogi i szyje tak, że trwają na miejscu i patrzą tylko przed siebie" (514a). Siedzą rzędami i obserwują na przeciwległej ścianie świat oświetlony blaskiem ogniska, ukazujący się im w postaci nieruchomych odbić ich własnych głów i cieni różnorodnych przedmiotów, które się poruszają. Zakute w kajdany osoby spostrzegają, że pojawianiu się, znikaniu i ponownemu zjawianiu się owych przedmiotów towarzyszą wypowiedzi słowne, które docierają do nich, podobnie jak światło ogniska, z części jaskini znajdującej się za ich plecami. Ruchome i nieruchome obrazy na ścianie i głosy, które im towarzyszą, prowokują mieszkańców podziemnego świata do dzielenia się swoimi obserwacjami ${ }^{17}$. Być może właśnie dzięki temu niektórzy z nich wpadają na pomysł, żeby zakładać się o to, jaki przedmiot ukaże się na ścianie jako następny.

Dla uwięzionych w jaskini oba źródła światła są nieznane. Nie wiedzą oni również tego, że ruchome obrazy na ścianie są tylko cieniami rzucanymi przez „różnorodne wytwory” (514a), które jacyś ludzie, chodzący wokół ogniska w tylnej części jaskini, noszą na swoich głowach. Mieszkańcy pieczary sądzą jednak, że to, co widzą i słyszą, oraz to, o czym ze sobą rozmawiają, jest prawdziwe. Ich komunikacja odbywa się w świecie, który jest im znany i bliski. Gdy pytają o jego porządek, odwołują się do swoich doznań, rozmów i przewidywań.

Treść edukacyjna Platońskiej metafory jaskini wynika z napięcia między znanym a nieznanym (obcym) w sytuacji, która staje przed oczami każdego, kto tę opowieść potraktuje poważnie. Czym dokładnie jest to napięcie, ukazuje się, gdy za znane uznamy istnienie jaskiń z otworami, które mogą służyć jako wejście lub wyjście. Znane jest też to, że w takich jaskiniach możemy mieć do dyspozycji dwa rodzaje oświetlenia: jedno pochodzące $\mathrm{z}$ rozproszonych promieni słonecznych, drugie wytwarzane „sztucznie”, np. przez ognisko. W przeciwieństwie do tego położenie ludzi, którzy znajdują się w jaskini przykuci do swoich siedzisk, wydaje się czymś nieznanym i obcym. Chociaż mogą oni obserwować poruszające się przed nimi obrazy, to jednak nie są w stanie zmieniać swoich pozycji. Dlatego nie widzą ogniska i przedmiotów rzucających cień na ścianę ani światła wpadającego z boku przez otwór wejściowy, które pochodzi od nieznanego im słońca. Platon wyraźnie odwołuje się do tej swojskości i obcości, gdy na początku opowieści wkłada w usta Glaukona słowa skierowane do Sokratesa: „Dziwny obraz opisujesz i kajdaniarzy osobliwych” (515a). Ten ostatni zaś odpowiada: „Podobnych do nas” (515a).

${ }^{17}$ Odnośnie do kształcącego oddziaływania różnicy między ruchomymi i nieruchomymi obrazami zob. też H. Niehues-Pröbsting, Platonvorlesungen ..., s. 351 i n. 
Zapytajmy zatem, jak opisane w metaforze jaskini zwyczajne (znane) i niezwyczajne (obce) stany wzajemnie się do siebie odnoszą i w jaki sposób Platon scala je, tak aby zinterpretować doświadczenia, które nabywają ludzie uczący się poprzez kształcenie. W obu przypadkach mieszkańcy jaskini dostrzegają to, o czym czytelnicy paraboli wiedzą od zawsze, dopiero wtedy, gdy jeden z nich dokonał podwójnej zmiany kierunku patrzenia i najpierw odwrócił swój wzrok od cieni na ścianie ku przedmiotom noszonym na głowach, a następnie spojrzał w stronę światła słonecznego, które przez otwór wejściowy wpadało do jaskini. Przy interpretowaniu tego, co w opowieści o jaskini jest dziwne, a co zwyczajne, Glaukon i Sokrates są zgodni, że skuci kajdanami uznają cienie na ścianie za „prawdę” (515b) oraz że w rozmowach informują się o tym nawzajem. Uważają również, że dialogi słyszane za ich plecami dotyczą tych samych przedmiotów, które oni widzą przed sobą, i wreszcie nie akceptują biernego obserwowania tego, jak owe przedmioty pojawiają się i znikają. Dlatego postanawiają uporządkować swoje doświadczenia przez formułowanie hipotez dotyczących tego, jaki przedmiot zobaczą następny.

Do zrekonstruowanego przez nas do tej pory procesu kształcenia, który przebiega w jaskini i w swej strukturze ma momenty bierne i czynne, dołącza jeszcze drugi. Rozpoczyna się on uwolnieniem z kajdan jednego z więźniów. Przykucie uniemożliwia u pozostałych osób, przytwierdzonych do swoich siedzisk, obrót głowy i zmianę kierunku patrzenia. Wyzwolony jest niejako zmuszony do zmiany swoich przyzwyczajeń i wyobrażeń. Jednakże nie wybiera on tej emancypacji z własnej woli i dlatego najpierw sprawia mu ona pewien ból, który dopiero po pewnym czasie nabierze sensu. Niemniej wyzwolenie spotyka nie wszystkich mieszkańców jaskini. Na początku uwolniony zostaje tylko jeden z nich. Przypadkowemu wybrańcowi losu zostały zdjęte kajdany i zmuszono go, żeby wstał i się odwrócił. Najpierw nie może patrzeć, gdyż oślepia go światło z ogniska. Następnie zaczyna rozpoznawać naczynia i ,posągi, i inne zwierzęta z kamienia i z drzewa, i wykonane rozmaicie" (514b), które noszą na głowach ludzie chodzący wokół ogniska.

$\mathrm{Na}$ następnym etapie Platon opisuje drugie źródło światła. Po tym jak wzrok wyzwolonego przyzwyczaił się do świata rozjaśnionego blaskiem ogniska, musi udać się on w kierunku wyjścia, przez które wpada jasna poświata i odbija się od bocznych ścian, rozpraszając mrok pieczary. Po wydostaniu się na zewnątrz człowiek ten musi spojrzeć prosto w słońce i rozejrzeć się po świecie opromienionym jego blaskiem. Tutaj ponownie mamy do czynienia z dynamiką kształcenia, którą przedstawiliśmy wcześniej. Po dwakroć wyzwolony z kajdan zostaje oślepiony przez słońce. Dopiero po chwili jest w stanie przyjrzeć się światu rozjaśnionemu promieniami, a w końcu spojrzeć w samo słońce. To, co spostrzega w tym momencie, uznaje za prawdę.

Pozostający jeszcze do omówienia ostatni etap kształcenia opisanego w metaforze jaskini jest pierwszym, który został dobrowolnie wybrany przez samego 
wyzwolonego. Gdy poznał już prawdy na temat cieni i świata rozświetlonego blaskiem ogniska oraz promieniami słońca, decyduje się wrócić do swoich współtowarzyszy i podzielić się z nimi tym, czego doświadczył i co poznał. Realizując to postanowienie, spotyka się po raz trzeci z rzędu z czymś dla niego samego zaskakującym, a mianowicie: wszystko, czego nauczył się do tej pory, wydaje mu się znów problematyczne. Z finału paraboli Platona można wysnuć wniosek, że zmiana przyzwyczajeń i reedukacja towarzyszą nie tylko wyzwoleniu wbrew własnej woli, lecz także dobrowolnemu powrotowi do jaskini. Ponadto dowiadujemy się, że wracający napotyka trudności, gdy chce przekazać pozostającym w jaskini to, czego nauczył się na zewnątrz. Ci ostatni sądzą, że wrócił on „z zepsutymi oczami” (517b), i chcą go nawet za to zabić, gdyż nie mogą znieść, gdy kwestionuje wszystkie ich dotychczasowe zwyczaje i wyobrażenia.

Sokrates i Glaukon w rozmowie na temat przypowieści dochodzą do dwóch następujących wniosków: po pierwsze, światło słoneczne wpadające do wnętrza jaskini przez otwór wejściowy i powodujące w niej półmrok wskazuje na ,ideę Dobra" (517b), która „w świecie myśli [...] rodzi prawdę i rozum” (517c) i jest „przyczyną wszystkiego, co słuszne i piękne” (517c), i po drugie, możliwa jest odpowiedź na postawione na początku opowiadania pytanie o fundamentalny dla ludzkiej natury stosunek między kształceniem a niekształceniem. Symbolizowana przez słońce idea Dobra odnosi się, zdaniem Platona, do koniecznego warunku wszelkiego uczenia się i kształcenia. Jest nim docierające do jaskini światło słoneczne, które symbolizuje transcendentny porządek racjonalny. Ludziom w procesach kształcenia dana jest jedynie możliwość zbliżenia się do tego porządku. Tylko w jednym miejscu omawianej opowieści znajdziemy szczegóły dotyczące idei Dobra oraz sposobu jej interpretowania. Tym wyjątkiem jest wypowiedź Glaukona deklarującego, że chce zawsze „postępować rozumnie” (517c), o ile oczywiście będzie potrafił. W przeciwieństwie do tego Platon nad wyraz obszernie rozważa kwestię stosunku między kształceniem a niekształceniem. Jego odpowiedź składa się z dwóch części: pięcioetapowego modelu ilustrującego przebieg procesu kształcenia oraz próby rozwiązania problemu wychowania, kształcenia i kierowania wspólnotą polityczną w świetle powyższego stosunku. Prześledźmy obie części odpowiedzi Platona.

Proces kształcenia opisany w paraboli jaskini dzieli się na pięć etapów i przebiega wielokrotnie. Pierwszy etap to przedstawienia, które uczący się dostrzega w życiu codziennym; wynikają one z obserwacji i informacji pochodzących z rozmów oraz z wymiany spostrzeżeń z innymi. W wiedzy poprzedzającej i umożliwiającej powstawanie tych przedstawień zostały zniesione i zapomniane początki uczenia się w ogóle ${ }^{18}$.

Nieoczekiwane wydarzenia rozpoczynają na drugim etapie nowy proces kształcenia, który u uczącego się początkowo wywołuje irytację, ponieważ musi

${ }^{18}$ Por. K. Meyer-Drawe, Anfänge..., s. 29-31. 
on zakwestionować cały świat rzeczy. W opowiadaniu Platona jest to chwila, gdy jednemu z mieszkańców jaskini przemocą zdjęto kajdany symbolizujące ograniczenia w doświadczaniu. Wskutek tego świat, z którym był wcześniej obeznany, stracił nagle swojski charakter i stał się obcy. To z kolei otworzyło uczącego się na nowe doświadczenia, najpierw w ,starych” ramach, a po pewnym czasie poza nimi.

Trzeci etap polega na opuszczeniu przez wyzwolonego jaskini, ale nie jaskini swojego wykształcenia, lecz tej, która poprzednio była wyjściem z jego codziennych doświadczeń. Dzięki temu może się rozpocząć proces zmiany przyzwyczajeń i reedukacji, który prowadzi do nowych doświadczeń. Na tym etapie, w przeciwieństwie do poprzedniego, nie chodzi już o to, żeby ostatnie doświadczenia uważać za prawdziwe, lecz żeby zastanawiać się nad tym, jak odkryć prawdę, która połączy dotychczasowe i przyszłe doświadczenia. Na ten problem można znaleźć odpowiedź tylko przez podjęcie wysiłku poszukiwania $\mathrm{w}$ świetle idei Dobra. Z naciskiem trzeba podkreślić, że owego Dobra nie da się wytworzyć samemu, lecz trzeba je założyć jako dane.

Ponieważ prawda nie objawia się w ramach doświadczenia będącego biernym doznawaniem lub sprawczym działaniem, ani poza nim, na czwartym etapie następuje powrót do jaskini doświadczenia. Jednak człowiek, podejmujący trud własnego kształcenia, uświadamia sobie, że ani on, ani świat, do którego wrócił, nie są takie, jakie były na początku.

$\mathrm{Na}$ piątym etapie powyższa konstatacja prowadzi „nawróconego" do $\mathrm{w}$ gruncie rzeczy rozczarowującego wniosku, że nie może on swoich nowych doświadczeń ani zachować wyłącznie dla siebie, ani przekazać tym, z którymi jeszcze nie tak dawno łączyły go wspólne przeżycia.

$\mathrm{Z}$ powyższych pięciu etapów kształcenia opisanych w trakcie rozmowy Sokratesa z Glaukonem Platon wyprowadza trzy wnioski. Pierwszy nawiązuje do wypowiedzi Glaukona, że obraz uwięzionych w jaskini jest dziwny, i do wskazania Sokratesa na ogromne podobieństwo przedstawionych tam doświadczeń z tym, co każdy człowiek wie z własnego życia (515a). Tak w pierwszym, jak i w drugim przypadku poszukiwanie prawdy obala hipotezę, że jest ona dana jako coś już gotowego. Przykład Sokratesa skazanego przez Ateńczyków na śmierć dowodzi, że proces kształcenia niesie ze sobą ryzyko i z jednej strony okazuje się bolesny dla tego, kto go przechodzi, z drugiej zaś dziwny i niezrozumiały dla tych, którzy nie znają go z własnego doświadczenia i oceniają tylko na podstawie obserwacji innych $(517 b-518 b)$.

Drugi wniosek brzmi następująco: komunikacja między ludźmi, którzy mniemają, że dzięki własnemu doświadczeniu posiedli pełnię prawdy, a tymi, którzy jej szukają, nie przebiega bezproblemowo i wiąże się z nieporozumieniami. Nauczanie nie polega na wkładaniu ,wzroku [...] w oczy ślepe” (518c) i przez to na czynieniu niewykształconych, to znaczy ślepych, widzącymi, lecz na opanowaniu sztuki zmiany kierunku patrzenia. W tej ostatniej punktem wyjścia jest ukształtowany sposób patrzenia na rzeczywistość. Według Platona przez pojęcie 
nauczania jako sztuki zmiany kierunku patrzenia należy rozumieć technikę takiego formułowania pytań i pokazywania, żeby uczący się, dzięki zachętom nauczającego, sam przeprowadził rewizję swojego sposobu postrzegania.

Ostatni, trzeci wniosek nie odnosi się do indywidualnych procesów kształcenia, lecz werbalizuje znaczenie, jakie przysługuje kształceniu (paideia) w życiu wspólnoty państwowej. Zdaniem Platona rządzić państwem nie powinni ani „ludzi ubodzy i [...] łaknący dóbr osobistych" (521a), gdyż nie są w stanie odwieść swojego wzroku od korzyści osobistych, ani pięknoduchy, którym ,się zdaje, że mieszkają gdzieś daleko, gdzieś na wyspach szczęśliwych" (519c). Tych ostatnich dyskwalifikuje przede wszystkim to, że wskutek nadmiaru wiedzy i dóbr materialnych koncentrują swoje myśli wyłącznie na prowadzeniu beztroskiego życia. Trzecią grupę osób nienadających się do kierowania wspólnotą państwową tworzą ci, „którzy się w rządzeniu kochają” (521b). Ostatecznie więc, według Platona, do rządzenia państwem najlepsi są ci, którzy mają rozwiniętą świadomość własnej niewiedzy i potrafią pytać o Dobro. Ich mocną stroną jest nie tylko to, że korygują swój własny kierunek patrzenia, lecz także to, że mają zdolność wspierania w tym zakresie innych (520a-521b).

\section{Jaskinia jako metafora nowożytnego i współczesnego myślenia o edukacji}

Z transformacją Platońskiej opowieści o jaskini w inne formy doświadczenia, myślenia i uczenia się spotykamy się już u Arystotelesa, który przekłada Platona koncepcję zmiany kierunku patrzenia przez kształcenie (periagoge) na wznoszenie się od doświadczenia na poziom znajomości celowościowego porządku rządzącego wszystkim, co istnieje (epagoge). W swojej Fizyce Arystoteles dość swobodnie nawiązuje do metafory mistrza i pisze o człowieku niewykształconym, który „stał się wykształconym” (189b) ${ }^{19}$. Dokonał tego dzięki ukierunkowaniu swojego kształcenia na właściwy człowiekowi cel.

W czasach nowożytnych bardziej niż Platońską zmianę kierunku patrzenia zakwestionowano właśnie Arystotelesowskie cofanie się do teleologicznych podstaw doświadczenia. Od Novum Organum Francisa Bacona z roku 1620 mówi się o stopniowym zaniku myślenia teleologicznego jako podstawy normatywnej kształcenia. Zdaniem Bacona w przyszłej edukacji - czy to w odniesieniu do jednostek, czy całej ludzkości - nie da się uniknąć rezygnacji z antycypacji filozoficznych. W postępowaniu naukowym za racjonalniejsze od nich uznawał on krytykę ideologii i indukcję empiryczną. Idole jaskini (idola specus), do których Bacon zalicza - za Arystotelesem - wyobrażenia o celowym porządku świata,

${ }^{19}$ Przytoczenie za: Arystoteles, Fizyka, przekł. K. Leśniak, [w:] tenże, Dzieła wszystkie, t. 2, Warszawa 2003. 
duszy, społeczeństwa i kosmosu, powinno się razem z idolami rynku (idola fori) i teatru (idola theatri) zastąpić formami wiedzy wypracowanymi przez nowożytną naukę. Ta ostatnia, jego zdaniem, obywa się bez wizji powstałych dzięki antycypacyjnej sile ludzkiego rozumu i ugruntowuje swoje aspiracje do prawdy na porządku boskich praw natury, który to porządek człowiek jest w stanie rozpoznać pod warunkiem, że będzie korygował swoje błędy i pomyłki. Tak koncypowana jest wiedza, w której zlewają się poznanie świata i władza człowieka w jedno. Bacon jest przekonany, że poznanie odwiecznych praw ustanowionych przez Boga umożliwi człowiekowi w przyszłości coraz większą partycypację w boskiej wszechmocy i w końcu doprowadzi do poddania ludzkiemu panowaniu nie tylko przyrody i duszy, lecz także moralności i historii.

Według Bacona nowożytna wiedza pozwoli osiągnąć to, co Platon wykluczył jako niepoznawalne, a Arystoteles udaremnił przez skupienie uwagi na celu. Z kajdaniarzy zamkniętych w Platońskiej jaskini, którzy jako arystotelicy przyzwyczaili się do myślenia i działania według z góry określonego porządku, powstaną kiedyś nowożytni adoratorzy wiedzy będącej zarazem władzą. Bacon w Novum Organum i Nowej Atlantydzie wyznacza kształceniu i nauce zadanie nałożenia - jeśli można tak powiedzieć - ślepym antycypacjom, które za sprawą myślenia teleologicznego powstały w starożytności i średniowieczu, okularów nowożytnej nauki i w ten sposób dodania skrzydeł postępowi naukowemu i społecznemu.

Mimo dobrych chęci Bacon nie rozpoznał granic scjentystycznego obrazu świata ani tego, że nowożytna nauka nie może uzurpować sobie wyłącznej swobody tworzenia antycypacji. Wynika to chociażby stąd, że jej niewątpliwe sukcesy wspierają się na ustanowionych przez ludzki rozum teoretyczno-hipotetycznych założeniach odnośnie do praw rządzących porządkiem świata. Według Karla R. Poppera prawdziwość wypowiedzi naukowych nie zależy od ich weryfikowalności, lecz od tego, czy poddają się falsyfikacji przez doświadczenie. Nieco później Theodor W. Adorno wykazał ,ślepotę" Bacona wobec ideologii nowożytnej nauki (idola tribus). W swojej Theorie der Halbbildung (Teoria ksztatcenia połowicznego) Adorno rozbudował Platońską diadę apaideusia - paideia do triady, która zawiera w sobie „niekształcenie”, „kształcenie” i „kształcenie połowiczne". Na szczególną uwagę zasługuje w niej to, że niekształcenie - jak to było już u Platona - poprzedza kształcenie i - inaczej niż u założyciela Akademii - następuje po kształceniu połowicznym. Adorno wyjaśnia „stoczenie się” kształcenia w połowiczne w ten sposób, że relacje uczenia się, zachodzące naturalnie między człowiekiem a światem, we wszystkich obszarach życia podlegają degradacji do pewnych tylko skrótów myślowych, które uczący się traktują jako z góry gotowe do przyswojenia. Zwalnia ich to z trudu prześledzenia sposobu powstania tych skrótów i zapamiętania tego. Współczesny świat charakteryzuje się dużym skomplikowaniem relacji między różnymi stanami rzeczy. To powoduje, że z jednej strony - jak to zademonstrował Platon - początki uczenia się muszą pozostać w ukryciu, z drugiej natomiast niepewne są cele, wpływy i następstwa kształcenia. 
Wobec tego ukształcalność - zarówno w przypadku jednostek, jak i narodów, społeczeństw, a wreszcie całej ludzkości - cechuje się ambiwalencją, której nie da się wyeliminować przez przyjęcie takiego czy innego porządku celów.

Po przestudiowaniu hermeneutycznej tradycji starożytności i nowożytności Hans-Georg Gadamer starał się uwolnić wywodzące się od Arystotelesa myślenie o kształceniu z teleologicznych implikacji. Jednocześnie dogłębnej krytyce poddał on Baconowski program dążenia do wolnego od przedsądów oświecenia naukowego, w którym prawda opiera się na władzy, a ta z kolei jest legitymizowana przez odniesienie do boskiego prawa natury ${ }^{20}$. Wykształconego od niewykształconego czy połowicznie wykształconego odróżnia, zdaniem Gadamera, nie bycie wolnym od przedsądów, lecz to, że je sobie uświadamia i jest gotowy do podjęcia dyskusji o tym, co go determinuje i ogranicza w myśleniu. Na tej podstawie Gadamer stwierdza, że starożytny sposób uprawiania nauki różni się od nowożytnego nie tym, że jakoby antycznych uczonych krępowały ich własne teleologiczne przedsądy, których nie byli w stanie nawet zauważyć, i dopiero w nowożytności osiągnięto zdolność myślenia wyzwolonego spod ich ciężaru. Zasadnicza różnica polega na tym, że starożytna i nowożytna nauka są oparte na odmiennych paradygmatach antycypacji. Zamiast jednej jaskini Platona, która dawała nadzieję na wyjście, współcześnie mamy do czynienia z pluralizmem jaskiń i zdemaskowanych gier językowych, które się w nich toczą. Konsekwencją tego jest konieczność dokonywania zarówno w jaskiniach, jak i między nimi wielokrotnych zmian kierunku patrzenia. Jedna metoda naukowa nie wystarcza, żeby poradzić sobie z tym zadaniem. Wciąż sporną kwestią pozostaje to, czy i jak możliwa jest mediacja między sprzecznymi poglądami na świat. To pytanie odnosi się zarówno do teorii kształcenia, jak i filozofii, nie mówiąc już o polityce.

Ważny wkład w zagadnienie rozumienia dyskutowanych tutaj problemów wniósł na początku wieku XX John Dewey. W swoim głównym dziele pedagogicznym Demokracja $i$ wychowanie zastąpił on obecne jeszcze w myśleniu Gadamera wyobrażenie, zgodnie z którym dorośli muszą najpierw wszystko wyjaśnić i odkryte przez nich rozwiązania przekazuje się potem pokoleniu dorastających, następującą myślą: bazą każdego doświadczenia jest ścieranie się wytwarzanych w pasywny i aktywny zarazem sposób antycypacji, które powstają pod wpływem niejednokrotnie bolesnego zmagania się ze światem. Według Deweya nowoczesny program kształcenia nie polega na uniformizacji czy standaryzacji doświadczeń, lecz na partnerskiej wymianie poglądów zróżnicowanych indywidualnie i społecznie. Tym sposobem Platońska jaskinia przekształca się u Deweya w jaskinię ludzkości, w której pierwszorzędne znaczenie zyskuje umiejętność rozróżniania między (wówczas dopiero krystalizującym się) społeczeństwem ogólnoświatowym a różnorodnością innych możliwych form ludzkiego zrzeszania się. W tym kontekście główny akcent pada na gotowość do zrezygnowania ze skostniałej tożsamości czy

${ }^{20}$ Zob. H.-G. Gadamer, Prawda i metoda, przekł. B. Baran, Warszawa 2004. 
to subiektywnej, czy też obiektywnejej ${ }^{21}$ Tego stwierdzenia nie trzeba od razu interpretować jako opowiedzenia się za źle rozumianą swobodą społeczeństwa wielokulturowego, w którym zagubiono więzy normatywne. Wprost przeciwnie - głos Deweya należy odczytywać w warunkach nowoczesności jako wezwanie do przywrócenia nadwątlonej i kruchej już w czasach starożytnych jedności między społeczeństwem a społecznością. Społeczeństwo jest, w jego opinii, otwartą przestrzenią, w której ludzie mogą swobodnie decydować o przystąpieniu lub nieprzystąpieniu do wybranych przez siebie społeczności. Te ostatnie nie są autarkiczne, lecz dochodzi między nimi - jako wyodrębnionymi grupami w ramach jednego społeczeństwa do wielorakich oddziaływań zwrotnych. Zdaniem Deweya demokracja jako forma wspólnoty życia opiera się na idei nieskrępowanej wymiany doświadczeń zarówno w odniesieniu do życia indywidualnego, jak i zbiorowego. Wprawdzie przy takim rozumieniu demokracji nie można obyć się bez Platońskiej idei Dobra, ale założenie teleologicznego porządku dóbr okazuje się niekonieczne.

Mimo to Dewey niedostatecznie przywiązywał wagę do problemów i konfliktów powstających wskutek niejednokrotnie sprzecznych interesów leżących u podstaw poszczególnych dziedzin praxis. Nie ustrzegł się również błędu niwelowania różnic między różnymi paradygmatami naukowymi przez jednostronne skupienie uwagi na pragmatyzmie, w którym widział uniwersalny instrument do rozwiązywania kwestii naukowych ${ }^{22}$. Niemniej jego idee są aktualne do dziś. W szczególności odnosi się to do pojęcia procesu wychowania. Dewey twierdzi, że tak jak inne procesy, ,nie ma [on] innych zewnętrznych w stosunku do siebie celów, jest celem sam w sobie”23. To z kolei oznacza, że jego istota zasadza się „na ciągłym reorganizowaniu, przekształcaniu i przemianach" ${ }^{24}$, których przedmiotem są wszystkie wyobrażenia, doświadczenia i umiejętności ${ }^{25}$.

\section{Rozszerzenie ,doświadczenia” i ,współuczestnictwa” oraz „godność praxis” jako nawiązania do Platońskiej metafory jaskini w teoriach Rousseau, Herbarta i Schleiermachera}

Deweyowska koncepcja ukierunkowanych na kształcenie oddziaływań zwrotnych między jednostkami, różnorodnymi formami zrzeszania się i tworzącą jakby jedną jaskinię demokratyczną opinią publiczną powstała na gruncie

${ }^{21}$ Zob. J. Dewey, Demokracja i wychowanie, przekł. Z. Doroszowa, Wrocław-WarszawaKraków-Gdańsk 1972, s. 113-120.

${ }^{22}$ Por. D. Benner, A. English, Critique and Negativity: Towards the Pluralization of Critique in Educational Practice, Theory and Research, ,Journal of Philosophy of Education” 2004, No 38, s. $409-428$.

\footnotetext{
${ }^{23}$ J. Dewey, Demokracja..., s. 71.

${ }^{24}$ Tamże.

${ }^{25}$ Zob. tamże, s. 71-75.
} 
społeczeństwa północnoamerykańskiego, które jako pierwsze na świecie włączyło do swojej ustawy zasadniczej ogólne prawa człowieka, chociaż realizację tych zapisów w odniesieniu do ciemnoskórych współobywateli, potomków niewolników sprowadzonych ongiś do Ameryki, zdołano przeforsować dopiero pół wieku po ukazaniu się programowego dzieła filozoficzno-pedagogicznego Deweya. Niemniej jego teorii kształcenia nie należy interpretować zbyt wąsko. Na szczególne podkreślenie zasługują w niej wyraźne ślady więzi myślenia Deweya z zapoczątkowaną przez Platona i Arystotelesa oraz sięgającą od Rousseau i Locke'a aż do Humboldta i Hegla europejską tradycją edukacyjną. Celem przedstawionych poniżej rozważań nie jest jednak analiza wpływu wskazanej tradycji na koncepcję Deweya, lecz systematyczna rekonstrukcja transformacji metafory jaskini w pismach Rousseau i Herbarta, które Dewey znał doskonale, oraz Schleiermachera, z którego myślą - jak się wydaje - nie zapoznał się dostatecznie wnikliwie.

Rousseau dał wyraz głównej idei nowożytnego kształcenia wyzwolonego ze schematów porządku teleologicznego w pojęciu perfectibilité. Odnosi się ono w takiej samej mierze do jednostek, jak do ludzkości en tout. Parabola jaskini nie zajmuje u Rousseau żadnego uprzywilejowanego miejsca, jednak można się do niej odwołać, aby uwydatnić nowatorskie rysy jego koncepcji wychowania i kształcenia. Autor Emila wyodrębnia w myśleniu różne, rozrzucone w czasie $i$ hermetycznie zamknięte, przestrzenie ludzkiego życia. Pierwszą z nich jest hipotetyczny stan natury, który cechuje się otwartą ukształcalnością człowieka, zwracającą go zarówno do dobrego, jak i do złego. Drugą przestrzenią jest antyczna polis. Rousseau w tej przestrzeni interpretuje człowieka jako obywatela i część państwa. Trzecia sfera to współczesne francuskiemu myślicielowi społeczeństwo mieszczańskie, w którym z jednej strony bezpowrotnie tracą ważność podziały stanowe związane $\mathrm{z}$ ancien régime, $\mathrm{z}$ drugiej natomiast wszyscy rywalizują ze sobą, dążąc do zdobycia poważania, sukcesu, bogactwa i sławy. Konkurencja ta wpływa tak mocno na ludzi, że nikt nie jest zdolny być ani człowiekiem, ani obywatelem. Rousseau przeciwstawia hipotetycznej przestrzeni stanu natury i społecznym przestrzeniom antycznej polis oraz społeczeństwa mieszczańskiego nowożytne wychowanie jako czwartą przestrzeń. W końcu przechodzi do piątej, historycznie jeszcze nieurzeczywistnionej, przestrzeni - republikańskiej formy współżycia społecznego. Dwie ostatnie sfery są nastawione jednocześnie na wspieranie rozwoju indywidualnego i uspołecznianie, przez co po raz pierwszy $\mathrm{w}$ historii powstaje szansa pogodzenia bycia człowiekiem i obywatelem $\mathrm{w}$ jednej i tej samej osobie ${ }^{26}$.

W Uwagach o rzadzie polskim i jego projektowanej naprawie Rousseau ukazuje polskim możnowładcom, którzy poprosili go o ekspertyzę na temat stanu Polski, pedagogiczną i polityczną trudność zbudowania w warunkach

${ }^{26}$ Zob. J. J. Rousseau, Emil, czyli o wychowaniu, przekł. W. Husarski, t. 1-2, Wrocław 1955. 
absolutystycznego systemu politycznego przestrzeni sprzyjającej nowoczesnemu wychowaniu i zaszczepieniu porządku republikańskiego:

Trzeba tych, którzy słuchają, którym chcecie dać wolność, przede wszystkim uczynić godnymi tej wolności i zdolnymi do udźwignięcia jej ciężaru. Jednak miejcie zawsze na względzie to, że należący do was chłopi są takimi samymi ludźmi jak wy; że posiadają w sobie to samo narzędzie, które umożliwi im stanie się tym, kim wy jesteście. Tym najpierw powinniście się zająć i dopiero wówczas uwolnić ciała, gdy dusze będą już wolne. Bez tej niejako drogi okrężnej wasze dzieło nie może się powieść ${ }^{27}$.

Kształtowanie indywidualności Rousseau uważa za konieczną „,drogę okrężną" prowadzącą do uformowania mentalności republikańskiej. Już wcześniej w Emilu, powieści prezentującej fikcyjny eksperyment wychowawczy przeprowadzony w przestrzeni pedagogicznej prowincji, przywodzącej na myśl jaskinię, doradca polskich arystokratów poddał pod dyskusję możliwość przejścia tej drogi $\mathrm{w}$ warunkach ancien régime. Rousseau w swoim dziele pełni funkcję jednocześnie autora, wychowawcy i wychowanka. Nie jest jednak jego zamiarem pokazanie tego, jak sztucznie da się wychować nowego, doskonałego człowieka. Chodzi mu raczej o prześledzenie kształcenia kogoś, kto nie żyje już w skostniałych ramach zamkniętego społeczeństwa feudalnego i jest „skazany” na samodzielne uczenie się odczuwania, myślenia, sądzenia i działania, w których uwzględnia się perspektywę prywatną, obywatelską i ogólnoludzką.

Emila można odczytywać jako literacko-estetyczną egzemplifikację nowego stylu wychowania, który powstał na skutek zmiany relacji międzypokoleniowej i wyodrębnienia się przestrzeni pedagogicznej nieoperującej już więcej odgórnie zdeterminowaną przyszłością, lecz tę przyszłość umożliwiającej. Estetyczne przedstawienie świata - przez Rousseau rozumiane jako medium komunikacji i środek kształcenia w okresie dojrzewania - dzięki Johannowi F. Herbartowi zyskało około roku 1800 rangę ogólnej metody wychowania. Jej zadanie polega na czymś więcej niż tylko na przygotowaniu dorastających do zajęcia określonego miejsca $\mathrm{w}$ społeczeństwie. W związku z otwartym horyzontem przyszłości metoda Herbarta umożliwia wpływanie na chcenie, myślenie i działanie dorastających ${ }^{28}$. Skoro w nowoczesnym wychowaniu nie przekazuje się dotychczasowych, zastanych form doświadczenia i współuczestnictwa, trzeba w sztuczny sposób, czyli przez kształcenie, zorganizować ich przekaz. Nauczanie szkolne musi, zdaniem Herbarta, rozszerzyć doświadczenie świata do triady złożonej z doświadczenia codziennego, naukowego oraz przeżyć estetycznych. Podobna triada musi powstać w odniesieniu do współuczestnictwa: osobiste doznania - polityka - religia ${ }^{29}$.

27 J. J. Rousseau, Uwagi o rzadzie polskim i jego projektowanej naprawie, przekł. A. Peretiatkowicz, [w:] tenże, Umowa spoleczna, Warszawa 1966, s. 203.

${ }^{28}$ Zob. J. F. Herbart, Estetyczne przedstawienie świata jako główne zajęcie wychowania, przekł. D. Stępkowski, „Pedagogika Kultury” 2008, t. 4, s. 13-27.

${ }^{29}$ Zob. J. F. Herbart, Pedagogika ogólna wywiedziona z celu wychowania, przekł. T. Stera, Warszawa 2007, s. 71-77. Por. także D. Stępkowski, Pedagogika ogólna i religia. (Re)konstrukcja 
Herbartowski program nauczania wychowującego obejmuje zatem dwie triady: doświadczenie codzienne - nauka - sztuka oraz współuczestnictwo polityka - religia. Punktem odniesienia albo celem, do którego zmierza nauczanie, jest kształtowanie w wychowanku woli i władzy sądzenia. Oznacza to rozwijanie kompetencji oceniania estetycznego, a także empiryczno-zdroworozsądkowego i hipotetyczno-scjentystycznego w odniesieniu do pierwszej triady, oceniania moralnego, politycznego i religijnego, jeśli chodzi o drugą. W tym miejscu należy mocno pokreślić, że głównym zadaniem nauczania wychowującego jest wspieranie w uczących się rozwoju własnego, wielostronnego kręgu myślowego. Drogą do tego prowadzącą jest budzenie w nich zainteresowania, po pierwsze, nowymi doświadczeniami, nauką i sztuką, które tworzą niedające się zastąpić formy oswajania się z rzeczywistością i jej problematyzowania, po drugie zaś współuczestnictwem, polityką i religią, będącymi przejawami praxis $\mathrm{i}$ interakcji.

Z naszkicowanej przez Platona sfery doświadczenia, którą symbolicznie wyraża jaskinia otwarta na prawdę, kształcenie i politykę, u Herbarta powstała przestrzeń obejmująca sześć zainteresowań i odpowiadających im aktywności. Wprowadzeniem do owej sfery ma być nauczanie, które rozszerza doświadczenie codzienne i współuczestnictwo. Dzięki nim zostaje utorowana droga do wyjścia - czy raczej przejścia - do doradztwa pedagogicznego (kierownictwo). Jeśli chodzi o zależność między niekształceniem a kształceniem, Herbart w swojej teorii podkreśla, że każdemu człowiekowi dana jest ukształcalność, która umożliwia mu uczenie się we wszystkich sześciu obszarach tworzących razem wielostronność zainteresowań. Kształcenie jest rozwijaniem partycypacji w niej. U podstaw tej koncepcji leży idea Dobra, którą Herbart wyłożył w Ogólnej filozofii praktycz$n e j$. Wolność definiuje się w niej jako konieczną do działania indywidualnego i społecznego zdolność zahamowania poruszeń własnej woli celem dokonania ich oceny. Kształcenie to wysiłek człowieka nad rozwijaniem w sobie wielostronnych zainteresowań. Życzliwość interpretuje autor jako bezinteresowną akceptację godności każdej osoby. Prawo oznacza w przypadku sporu między stronami poszukiwanie rozwiązania i uzgadnianie warunków umowy. Owa umowa - dzięki temu, że oparta jest na wolności, kształceniu i życzliwości - może ugruntować w kontrahentach wzajemny szacunek. Gdy jednak zostanie naruszona lub zerwana, należy odwołać się do słuszności. Przez słuszność Herbart rozumie zdolność dwoistej reinterpretacji złamanego prawa: po pierwsze, celem jego optymalizacji, po drugie, by zrekompensować straty poniesione przez stronę, którą skrzywdzono oraz by ukarać tę, która pogwałciła uzgodnienia zapisane w umowie.

Analogiczne rozróżnienie przeprowadza Herbart w przestrzeni życia społecznego. Jego zdaniem można w niej wyodrębnić systemy: prawa, sprawiedliwości,

zapomnianego watku na podstawie teorii Johanna F. Herbarta i Friedricha D. E. Schleiermachera, Towarzystwo Naukowe Franciszka Salezego, Warszawa 2010, s. 109-117. 
administracji i kultury. Dochodzi między nimi do różnorakich sprzężeń, których nie da się regulować ani na poziomie jednostki, ani państwa. Jedynym wyjściem jest scalenie wszystkich systemów w ukierunkowanej na ideę Dobra przestrzeni społeczeństwa uduchowionego ${ }^{30}$. Wprowadzony przez Herbarta zwrot „społeczeństwo uduchowione" można odczytywać jako przeddemokratyczny odpowiednik Deweyowskiej wizji demokracji będącej międzypokoleniową wspólnotą życia.

Wpływy Platońskiej metafory jaskini i idei poszukiwania dobra przez wielokrotne zwroty w patrzeniu były obecne nie tylko w Herbarta koncepcji nauczania wychowującego i poradnictwa pedagogicznego. To ostatnie ma za zadanie utorować drogę do współpracy międzygeneracyjnej. Innym autorem, który wpisuje się w tę tradycję, jest Schleiermacher. Dowody na to można z łatwością znaleźć w jego teoriach wychowania i Dobra najwyższego. W dotychczasowych opracowaniach skupiano się przede wszystkim na związku dialektyki i hermeneutyki Schleiermachera z sokratejsko-platońską mejeutyką ${ }^{31}$ i na powinowactwie jego nauki o najwyższym dobru z Platońską ideą Dobra ${ }^{32}$. Natomiast wciąż za mało uwagi poświęca się dokonanej przez Schleiermachera rewizji zależności między apaideusia (niekształcenie) a paideia (kształcenie), która zaczerpnięta jest bezpośrednio z opowiadania Platona o jaskini. Schleiermacher swoją propozycję nowego wymierzenia i uporządkowania drogi kształcenia przedłożył w dwóch wczesnych dziełach literackich, a mianowicie w wydanych w roku 1799 Mowach o religii do niewykształconych spośród tych, którzy niq gardza i w powstałych w tym samym czasie, ale opublikowanych w następnym roku Monologen (Monologi) ${ }^{33}$. Warto przyjrzeć się bliżej, na czym owa rewizja polega.

Według Schleiermachera jedynymi osobami, które są „godne” i „zdolne" pojąć tajemnicę kształcenia i jednocześnie rozwinąć w sobie wrażliwość na religię, są pogardzający religią wykształceni ${ }^{34}$. W przeciwieństwie do nich niezdolni do zgłębienia prawdziwego pojęcia religii są przedstawiciele dwóch innych grup: po pierwsze, intelektualiści oświecenia, którzy hołdują postawie racjonalistyczno-ateistycznej cechującej się dążeniem do całkowitego wyeliminowania religii przez rozum, i po drugie, fideiści, którzy nie do końca poważnie

${ }^{30}$ Zob. J. F. Herbart, Ogólna filozofia praktyczna, przekł. D. Stępkowski, „Studia Philosophica Wratislaviensia" 2008, nr 3, s. 121-148.

${ }^{31}$ Por. H. G. Gadamer, Prawda ..., s. 250-280; N. Vorsmann, Die Bedeutung des Platonismus für den Aufbau der Erziehungstheorie bei Schleiermacher und Herbart, Ratingen 1968, s. 23-120.

32 Por. F. Brüggen, Freiheit und Intersubjektivität. Ethische Pädagogik bei Kant und Schleiermacher, mpis, Universität Münster 1986, s. 48-76; D. Stępkowski, Pedagogika..., s. $187-193$.

${ }^{33}$ Por. Ch. Ehrhardt, Religion, Bildung und Erziehung bei Schleiermacher, Göttingen 2005.

${ }^{34}$ Zob. F. D. E. Schleiermacher, Mowy o religii do niewykształconych spośród tych, którzy nia gardza, przekł. J. Prokopiuk, Kraków 1995. 
traktują nowożytną naukę i z lekceważeniem odnoszą się do konfliktu wiedzy i wiary, domagając się dla tej ostatniej bezwzględnego uznania i pierwszeństwa. W sporze tym obie grupy wzajemnie się oskarżają o połowiczne wykształcenie. Oświeceniowi „bohaterowie rozumu” zarzucają fideistom, że nie są w stanie pojąć, czym jest nowożytna nauka i związana z nią racjonalność. Z kolei fideiści posądzają ateistycznie nastawionych racjonalistów o to, że nie widzą różnicy między konstrukcjami rozumu a realnym światem, którego egzystencja może być wyjaśniona tylko jako dany uprzednio stan rzeczy - ustanowiony notabene przez Boga.

Wykształcone osoby, które pogardzają religią, są podobne zarówno do ateistów, jak i fideistów, a zarazem odróżniają się od obu tych grup. Z jednej strony podzielają - w opozycji do fideistów, a przez to w zgodzie $\mathrm{z}$ ateistami - poglądy oświecenia, $\mathrm{z}$ drugiej natomiast są otwarte - w przeciwieństwie do ateistów i tak jak tego chcą fideiści - na uczucia religijne. W związku z tym jako jedyne w pełni rozumieją rozbieżność między racjonalistycznym a religijnym poglądem na świat - to zatem, co negują zarówno ateiści, jak i fideiści. Pierwsi czynią to, powołując się na rozum, drudzy argumentują opierając się na religii. Z przedstawionych trzech grup tylko pogardzający, zdaniem Schleiermachera, są zdolni do kształcenia (ukształcalności) w pełnym tego słowa znaczeniu. Rozumienie pojęcia ukształcalności wyprowadza on z sensu, jaki greckiemu terminowi apaideusia nadał Platon w swoim dziele pt. Państwo i wyjaśnił w Protagorasie przez odwołanie do epimejskiej natury człowieka. Zgodnie z tym ujęciem, charakterystycznym rysem człowieka jest bycie akosmetos, czyli nieozdobionym, albo lepiej: niekompatybilnym z punktu widzenia porządku świata (gr. kosmos). Schleiermacher w sporządzonym przez siebie przekładzie Protagorasa przetłumaczył akosmetos za pomocą niemieckiego przymiotnika unbegabt $(321 \mathrm{c})^{35}$, to znaczy pozbawiony uzdolnień, a więc nieokreślony i podatny na kształtowanie. Podczas gdy niewierzący racjonaliści przekonują siebie, że w ludzkim rozumie znaleźli miarę wszystkiego, fideiści czynią w pewnym sensie to samo, wysuwając na czoło wiarę. Ani jedni, ani drudzy nie są w stanie zmienić kierunku swojego patrzenia, czyli oderwać wzroku od światopoglądu racjonalistycznego i zwrócić się ku uczuciom religijnym oraz vice versa. Tylko ci, którzy są naprawdę wykształceni, pojmują, że oba elementy - racjonalny „ogląd wszechświata” i „uczucie” religijne - są ściśle ze sobą powiązane. Rozbieżności między nimi umożliwiają natomiast jeszcze wyraźniejsze ukazanie się „transcendentnej podstawy", której nie może zgłębić do końca ani pojedynczy człowiek, ani zbiorowość. Aby podkreślić wagę tej podstawy, Schleiermacher w Mowach o religii wprowadza dwa zwroty: „zależność od uniwersum” (Abhängigkeit vom Universum) i „poczucie absolutnej zależności” (Gefühl der schlechthinnigen

\footnotetext{
${ }^{35}$ Platon, Protagoras, przekł. na niem. F. D. E. Schleiermacher, [w:] tenże, Werke in 8 Bänden, t. 1, Darmstadt 1977.
} 
Abhängigkeit). W traktacie dogmatycznym Der christliche Glaube (Wiara chrześcijańska) oddaje to wyrażenie jako „zależność człowieka i świata od Boga" (Abhängigkeit des Menschen und der Welt von Gott).

W Schleiermacherowskiej interpretacji religii jako fenomenu nierozdzielnie związanego z człowiekiem pobrzmiewa sens etymologiczny łacińskiego czasownika religare, który znaczy 'wiązać, spajać ponownie'. Na tej podstawie można stwierdzić, że kształcenie religijne interpretuje świat i człowieka z punktu widzenia ich zależności od transcendentnej podstawy, którą jest miłujący swoje stworzenie Bóg. Tylko Jemu zawdzięczamy ponowne zjednoczenie tego, co musi na zawsze pozostać cząstkowe i niesatysfakcjonujące, jeśli zagubi się odniesienie do Niego. Schleiermacher pozostawił trzy wykładnie zapośredniczenia między wyrastającym z tradycji Baconowskiej obrazem świata, w którym rzeczywistość wyjaśnia się racjonalistycznie, a uczuciem religijnym, które umożliwia przezwyciężenie ograniczeń myślenia scjentystycznego, nie wyczerpując się w żadnym z dwóch wymiarów człowieka: bycie-w-świecie i koegzystencja.

Owe trzy wykładnie odnoszą się do teorii poznania, teorii kształcenia i teorii działania. Nowoczesnemu wychowaniu Schleiermacher wyznacza zadanie indywidualnego i społecznego (uniwersalnego) kształcenia jednostki w taki sposób, aby mogła partycypować w życiu wielkich wspólnot etycznych, którymi są wolna towarzyskość (obyczajowość), państwo (polityka), Kościół (religia) i organizacje naukowe (wiedza). Przez Dobro najwyższe Schleiermacher nie rozumie dobra znajdującego się na szczycie tak czy inaczej określonej hierarchii dóbr, lecz ideał „współdziałania międzypokoleniowego" (Mitgesamttätigkeit) ${ }^{36}$, czyli zespolenia w jedno funkcjonujących w młodym i starszym pokoleniu sposobów odczytywania rzeczywistości i działania w niej. Ostatecznym fundamentem tej koncepcji nie jest jednak samostanowienie czy samorealizacja człowieka, lecz idea Dobra. Starożytność interpretowała ją kosmologicznie i teleologicznie, w nowożytności natomiast akcent pada na otwartość i egalitarystyczną niehierarchiczność. Dlatego w pełni zrozumiałe wydaje się to, dlaczego Schleiermacher strażnikiem dobra najwyższego nie czyni religii, lecz współdziałanie wszystkich ludzi. Jak zasygnalizowano powyżej w związku z ideałem „współdziałania międzypokoleniowego”, prawo do partycypacji w tak określonym powszechnym dyskursie przysługuje na równi dorosłym i dorastającym. Tych ostatnich trzeba stopniowo zaznajamiać z problemami i rozbieżnościami towarzyszącymi poszukiwaniu konsensusu wśród zróżnicowanych form myślenia i sfer działania. Pod tym względem historia świata zawsze była, zdaniem Schleiermachera, pełna dyskursów i kontrowersji. Trzeba je traktować jako dowody „godności praxis” (Dignität der Praxis) ${ }^{37}$ i żywotności idei Dobra.

${ }^{36}$ F. D. E. Schleiermacher, Die Vorlesungen aus dem Jahre 1826, [w:] tenże, Ausgewählte pädagogische Schriften, oprac. E. Lichtenstein, Paderborn 1959, s. 45.

${ }^{37}$ Tamże, s. 40. 


\section{Nieprzemijające edukacyjno-teoretyczne znaczenie Platońskiej metafory jaskini, czyli o roli negatywnych doświadczeń w procesach kształcenia}

Zrekonstruowane powyżej - historycznie i systematycznie - transformacje paraboli Platona były impulsem do powstania wielu koncepcji kształcenia. Platońska jaskinia stała się nowożytnym uniwersum. Sokratejsko-platońska koncepcja zmiany kierunku patrzenia przekształciła się w wielość form doświadczenia, refleksji i działania. W związku z tym warto zapytać, czy współcześnie metafora Platona może mieć jeszcze jakieś znaczenie, a jeżeli tak, to na czym ono polega?

Początkowo jaskinia była dla Platona miejscem, w którym skuci kajdanami z trudem mogli zmieniać swój sposób widzenia świata. Mimo to niektórym $\mathrm{z}$ nich udało się skierować wzrok $\mathrm{w}$ inną stronę. $\mathrm{Z}$ naciskiem należy podkreślić, że pierwszych impulsów do tego dostarczyły im obserwacje przedmiotów poruszających się na ścianie i rozmowy z towarzyszami niedoli. Szczegółowo opisana przez Platona próba radykalnej zmiany (przekształcenia) patrzenia przez kontakt ze znajdującym się na zewnątrz jaskini światem, o którym informuje we wnętrzu rozproszone światło, kończy się niepowodzeniem, ale nie dlatego, że w ogóle nie zostaje przeprowadzona, lecz z tego powodu, że ci, którzy zostali w jaskini, nie są w stanie zmienić swojego widzenia. Wniosek, jaki stąd wypływa, jest następujący: nie można myśleć o kształceniu jak o procesie wyłącznie indywidualnym, co więcej, w tej formie jest on w ogóle niemożliwy. Pomimo różnorodnych zwrotów kierunku patrzenia każdy musi przeprowadzić je w sobie sam. Warunkiem ich dokonywania jest istnienie społecznej przestrzeni międzypodmiotowej, w której może toczyć się dyskusja, a niekiedy również spór o właściwą interpretację. Kształtująca siła edukacji nie leży w dokonywaniu, niejako za uczących się, zmian w kierunku ich patrzenia, gdyż - jak przed chwilą zostało powiedziane - jest to zadanie, które muszą wykonać oni sami, lecz w tym, co wydarza się między różnymi płaszczyznami widzenia.

Powstają tam negatywne doświadczenia, irytacje, nieścisłości, kłopoty ze zrozumieniem i zaskakujące konstatacje. W nich właśnie kryje się siła kształcenia. Dlatego nieodparcie narzuca się myśl, że koncepcja zmiany kierunku patrzenia przez nauczanie może przysłaniać - a niekiedy nawet całkowicie zamknąć - dostęp do kształcącego doświadczania edukacyjnego. Dzieje się tak wówczas, gdy nauczanie zakłada swobodną wymienność, czy raczej wymienialność perspektyw patrzenia. Coś takiego de facto wcale nie istnieje. Wynika to stąd, że w procesie kształcenia napotykamy swoistą przemoc, która wbrew naszej woli zmienia nasz dotychczasowy sposób myślenia. Jednak zmiana kierunku patrzenia nie jest kształcąca sama przez się, lecz przez zawarte w niej doświadczenie odmienności (inności) świata, własnych odczuć, myśli i chęci. Gdy uczący się 
uświadomi je sobie, wówczas zachwieje się to, co do tej pory wydawało mu się oczywiste i bliskie. Dopiero wtedy może on rozpocząc proces kształcenia, który był dotąd niemożliwy.

Każdemu, kto się uczy, niepewne wydają się nie tylko początki własnego kształcenia, lecz także jego cele i momenty kluczowe. Za normalne należy więc uznać, że to obowiązkiem nauczyciela jest wiedzieć, czego uczeń ma się uczyć, gdyż ten ostatni nie jest $\mathrm{w}$ stanie $\mathrm{z}$ góry przewidzieć, dokąd jego nauczanie prowadzi. W tym kontekście można mówić o jeszcze jednym nieprzemijającym znaczeniu Platońskiej metafory jaskini. Polega ono na tym, że uczenie się nie jest nieprzerwane i łatwe, ale wprost przeciwnie, nieciągłe i bolesne. W uczeniu się - czy to własnym, czy obcym - wielokrotnie dokonują się zmiany kierunku patrzenia. Tych zwrotów nie da się załatwić za jednym razem. Z tego wynika konieczność ciągłego przepracowywania negatywnych doświadczeń i irytacji wywołanych przez nowe przeżycia. W ten sposób możemy ciągle uczyć sie czegoś nowego. To, że coś aktualnie znanego i „oswojonego” było kiedyś nieznane i „nieoswojone”, zanim stało się oczywiste, jest najlepszym argumentem za uznaniem „godności praxis" (Schleiermacher). Jej źródłem jest wskazujący na ideę Dobra stosunek między niekształceniem a kształceniem. 